\title{
Disinvestment of Public Sector Enterprises (PSEs) and Fiscal Deficit Tackling in India
}

\author{
K.A. Aneesh \\ Research Scholar, Centre for Economic Studies and Planning (CESP), School of Social Sciences (SSS), \\ Jawaharlal Nehru University (JNU), New Delhi, India \\ E-mail: aneeshka99@gmail.com
}

\begin{abstract}
Every year since 1991, the Central Government of India has been successfully disinvesting its PSEs from various sectors. The recent announcement to strategically disinvest some of the better performing PSEs like Life Insurance Corporation of India Ltd., Air India and so on is indeed shocking. This seriously questions the intension of the government towards the declared objectives of the disinvestment strategy in 1991. There are severe apprehensions on selling-off the PSEs at a lower price and the utilization of disinvestment proceeds for filling the revenue deficits of the Central Government. This paper discusses the idea of disinvestment in India and the debates associated with it. The paper also critically analyses the disinvestment proceeds in India as a tool to tackle mounting fiscal deficits after the initiation of the New Economic Policies in 1991.
\end{abstract}

Keywords: Disinvestment, Privatization, New Economic Policies, Public Sector Enterprises, Fiscal Deficit

\section{INTRODUCTION}

The Public Sector Enterprises (PSEs) in India have contributed profoundly to develop the industrial base of the country, while several problems have begun to manifest themselves in many of the public enterprises in the late 1980s. Severe concerns were their insufficient growth in productivity, poor project management, over-manning, lack of continuous technological up-gradation, inadequate attention to research and developments and human resource development. The low rate of return on capital invested has constrained the ability of PSEs to regenerate themselves in terms of new investment as well as in new technology development. This resulted in many of the PSEs becoming a burden rather than an asset to the government. Some economists have argued that the fiscal crisis of 1991 was a result of the public sector's inability to generate an adequate return on investment (Jalan, 1992). The public sector policy in the 1960s and 1970s which has been guided by the Industrial Policy Resolution of 1956, gave the public sector a strategic role in the economy, has marked a change in the perception towards the role of PSEs since 1991. The new approach was to encourage privatization in India.

Privatization is the process by which the government transfers the productive activity from the public sector to the private sector. Stuart M. Butler (1986) defines privatization as "the transfer of government assets or functions to the private sector". Furthermore, according to D.R. Pendse (1985), “Any process which reduces the involvement of the state or the public sector in the economic activities of the nation, is a privatization process”.

Butler (1986) distinguishes four forms of privatization. First, the complete form of privatization is to sell government-owned assets to private buyers, removing government entirely from any involvement in the activity. The second form of privatization called 'deregulation' involves simply transferring to private sector services presently under government monopoly. The third form of privatization is 'contracting out', where the government continues to fund the services but invites private entrepreneurs (individual or corporate) to bid for the right to provide the service under contract. In the fourth form of privatization, known as 'vouchers', the government continues to fund the service, but instead of a government agency giving a contract to a private firm to provide a service, the agency gives the users of the service the meansprobably a voucher- to purchase the service in the open market.

In India, the term disinvestment is used rather than privatization. Privatization implies a change in ownership resulting in a change of management, while disinvestment may or may not lead to a change of management. The disinvestment of PSEs means the sale of public sector equity, leading to a weakening of government's stake. Thus, disinvestment implies the sale of shares (ownership) of the PSEs to outsiders conferring to right ownership to these units. This disinvestment may take place in the form of sale of partial shares of the PSUs to the private entrepreneurs or all of their shares to private entrepreneurs.

\section{THE DEBATE}

The New Industrial Policy, 1991, advocated privatization of public sector enterprises. Consequently, the Industrial Policy Statement of $24^{\text {th }}$ July 1991 stated that the government would disinvest part of its holdings in selected PSEs, but did not place any cap on the extent of disinvestment (GoI, 1991). The objective for disinvestment has stated to be to provide further market discipline to the performance of public enterprises. For purposes of privatization, the government has adopted the route of disinvestment, which involves the sale of public sector equity to the private sector and the public at large. 
The Interim Budget 1991-92 stated, "It has been decided that government would disinvest up to 20 percent of its equity in selected PSEs, in favour of mutual funds and financial or investment institutions in the public sector. The disinvestments, which would broad base the equity, improve management and enhance the availability of resources for these enterprises, is also expected to give Rs. 2500 crore to the exchequer in 1991-92"(GoI, 1992).

Following that, Budget Speech 1991-92 gave more clarity to the concept, and stated that,

"In order to raise resources, encourage wider public participation and promote greater accountability, up to 20 per cent of Government equity in selected public sector undertakings would be offered to mutual funds and investment institutions in the public sector, as also to workers in these firms"(GoI, 1992).

The primary approach of the government in this regard was to bring down its equity in all non-strategic public sector undertakings to 26 percent (or lower) and close down those public sector undertakings which cannot be revived. In its first budgetary pronouncement 1998-99, the new government decided to bring down government shareholding in the PSUs to 26 percent in the generality of cases, thus facilitating ownership changes, as was recommended by the Disinvestment Commission. In the Budget Speech 2000-01, for the first time, the government made the statement that it prepared to reduce its stake in the non-strategic PSEs even below 26 percent if necessary, that there would be increasing emphasis on strategic sales and that the entire proceeds from disinvestment/privatization would be deployed in the social sector, restructuring of PSEs and retirement of public debt. The disinvestment programme began in 1991-92, and government stakes in different public sector companies have been sold in varying degrees by 2004-05. Till 1998-99, the government used to sell minority stakes through the domestic or international issue of shares in small trances every year. Post 1999-2000, there has beengreater stress on strategic sale- involving an effective transfer of control and management to a private entity, the argument is that the government would get a better price from the private sector it is ceding actual control (Rubi, 2008).

The relevance of privatization of PSEs in India is justified on the following grounds:

1. Solution to the problem of low profitability and inefficiency in PSEs.

2. End of political interferences in economic decisions.

3. Increase in government reserves through the sale of the share of PSEs.

4. Freedom from pulls and pressures on the budget due to the losses in PSEs.

5. Solution to the problem of lack of autonomy, inadequate management incentive, etc.
6. Convert 'public sector' to 'people sector' by selling the shares of PSEs to the general public, and

7. Synchronizing with economic liberalization wave in the world (Gupta, 1998).

Disinvestment proceeds, which did not exist before 1991-92 are included in the capital receipts in India but are considered as revenue receipts in the definition of fiscal deficit of IMF and WB. There is an extensive discussion in the literature on disinvestment proceeds, whether to include it as revenue receipts or capital receipts. Mansoor (1988) discussing the above issue in detail argued that since the portfolio of government due to disinvestment does not change, i.e., the government only exchanges public asset with cash; disinvestments have no impact on the financial position of the government.

One view is that disinvestment proceeds are used to repay the borrowing, and the disinvested PSEs are loss-making, then it will gain in the future by the amount of interest payment and the loss of the PSEs. In the case of repayment of loans, it will be like an investment, so disinvestment, in this case, should be taken as a capital item. If disinvestment proceeds are used to finance current expenditure, then it should be included in the revenue receipts.

In India, the central government is using disinvestment proceeds neither for the restructuring of the loss-making public sector nor for liquidation of public debt as was the initial declared objective of the disinvestment. The proceeds are being used to finance the deficits in the current account. So, in this argument, disinvestment should be considered in the current (revenue) receipts. Fiscal deficit of the government will go down by the amount of disinvestments. However, Mansoor (1988) shows that it is a one-shot game, and it reduces the present borrowing requirements at the cost of a higher future deficit.

In Kumar (1994), disinvestment is treated as a negative investment by the public sector and netted out of the total capital expenditure by the government. The deficit stands reduced. The private sector which purchases the assets then reduces investment elsewhere. Hence, total investment in the economy stands reduced as a result of the disinvestment. Chelliah (1996) argued that if the short-term impact of the budget on aggregate demand through the net borrowing is to be judged, the sale proceeds of assets could be netted against capital formation expenditure. In this case, the sale proceeds will not be shown as a source of financing deficit. However, if one wishes to measure the extent of the fiscal correction or adjustment in a situation where the size of the fiscal deficit has been too high, it would seem to be appropriate to consider the reduction in the deficit without taking into account the yield from the sale of assets. For this purpose, the sale proceeds should be taken to be an item financing capital expenditure. Chelliah's suggestion is situational, which cannot be accepted if one wishes for a consistent deficit measure. 


\section{UNDERVALUATION OF PSE'S ASSETS}

If we go through the target and investment proceeds since 1991-92, which is illustrated in Table 1, it will be evident that though there is an increasing trend in the target, it is not nearly so in the achievements. The disinvestment proceeds exceeded the target only in six years out of 27 years.

According to Chandrashekhar and Ghosh (2002), the success in 1991-92 was due to decision to accept extremely low bids for share 'bundles' which included equity from the Public Sector Units (PSUs) which would have otherwise commanded a handsome premium.

The average price at which more than 87 crore shares were sold in this year was only Rs.34.83 as compared with the average price realization of Rs.109.61 since then. In 199495, success was due to the off-loading of a significant chunk of shares in every attractive and profitable PSUs like BHEL, Bharat Petroleum, Container Corporation of India, Engineers India, GAIL, MTNL etc. Moreover, in 1998-99, the success was due to the reason that cash-rich PSUs like ONGC, GAIL and IOC were forced to buy shares of other PSUs.

This amounted to forcing PSUs, that needed further investment themselves to be restructured, to face up to the more liberal and competitive environment, to hand over their investible surpluses to finance the fiscal deficit of the government. The success in 2003-04 was primarily due to sale of 142.60 million shares in ONGC, which fetched as much as Rs.106.95 billion.

The amount realized was less than 10 percent in three years, and less than 50 percent in eight years, excluding those five years' governments did not set any targets (see Table 1). The main reasons for this poor performance were as follows:

1. The government carried out the whole exercise of disinvestment in a hasty, unplanned and hesitant way. Thus, it failed to realize not only the best value but also the other objectives of the disinvestment programme.

2. The government launched the disinvestment programme without creating the required conditions for its take-off. This would be clear from the fact that it did not try to list the shares of the public sector enterprises on the stock exchanges. Thus, adequate efforts were not made to build-up the much-needed linkage between the public enterprises on the one hand and the capital market on the other.

3. The government did not adopt suitable methods to oversee the disinvestment of public sector shareholding.

4. The Department of Public Enterprise and the Finance Ministry adopted techniques and methods which resulted in far lower realization than justified.
'Under-pricing' of public enterprises shares implies considerable losses for the government and therefore for the tax-paying citizens of the country. There is a fundamental problem with all privatization of public assets, which means that they tend to be associated ultimately with losses to State exchequer rather than gains.

If the government sells the asset that provides income or profit equal to more than the prevailing interest on government securities, then the government would lose future income by selling it. On the other hand, from the private sector's point of view, it makes no sense to purchase an asset unless it provides at least a rate of return equal to the rate of interest on government securities because that is where the private investor could otherwise put the money.

This means that for such sales to occur, either (a) the private investor must believe that it is capable of generating more profits than the public sector- but that is essentially a management issue and there is no logical reason why the public sector cannot employ managers to achieve this; or (b) the asset must be undervalued so that the actual rate of return for the private buyer turns out to be higher, which really means that the state exchequer has lost the money (Chandrashekhar and Ghosh, 2002).

Undervaluation of PSEs points to the prevalence of widespread corruption on the one hand, and complicity between sections of the government and particular business groups on the other hand (in the case of strategic sales). In this context, the comments of joseph Stiglitz (2003) are pertinent,

"Perhaps the most serious concern with privatisation, as it has so often been practiced, is corruption. The rhetoric of market fundamentalism asserts that privatisation will reduce what economists call the "rent-seeking" activity of government officials who either skim off the profits of government enterprises or award contracts and jobs to their friends. But in contrast to what it was supposed to do, privatisation is jokingly referred to as "briberisation". If a government is corrupt, there is little evidence that privatization will solve the problem. After all, the same corrupt government that mismanaged the firm will also handle the privatisation" (Stiglitz, 2003: 58).

India has missed the comprehensive understanding of the approach resorting to mostly financial restructuring, which could not produce the desired results. India has fallen prey to the short-term objective of raising revenues, leading to the partial realization of benefits. Therefore, our disinvestment programme should be exercised to achieve the long-term objective of enhancing competition, promoting optimum allocation of resources, etc. Thus, the government carried out the whole exercise of disinvestment in a hasty, unplanned and hesitant way. Thus, it failed to realize not only the best value but also other objectives of the disinvestment programme. 
TABLE I DISINVESTMENT TARGET AND REALIZATION

\begin{tabular}{|c|c|c|c|}
\hline Year & $\begin{array}{l}\text { Target } \\
\text { (Rs. In } \\
\text { Billion) } \\
\end{array}$ & $\begin{array}{c}\text { Realisation } \\
\text { (Rs. In } \\
\text { Billion) } \\
\end{array}$ & $\begin{array}{c}\text { Achievement } \\
\text { (as \% of } \\
\text { target) }\end{array}$ \\
\hline 1991-92 & 25.00 & 30.38 & 121.52 \\
\hline 1992-93 & 25.00 & 19.61 & 78.44 \\
\hline 1993-94 & 35.00 & -0.48 & -1.37 \\
\hline 1994-95 & 40.00 & 50.78 & 126.95 \\
\hline 1995-96 & 70.00 & 3.62 & 5.17 \\
\hline 1996-97 & 50.00 & 3.80 & 7.60 \\
\hline 1997-98 & 48.00 & 9.12 & 19.00 \\
\hline 1998-99 & 50.00 & 58.74 & 117.48 \\
\hline $\begin{array}{c}1999- \\
2000\end{array}$ & 100.00 & 17.24 & 17.24 \\
\hline 2000-01 & 100.00 & 21.25 & 21.25 \\
\hline 2001-02 & 120.00 & 36.46 & 30.38 \\
\hline 2002-03 & 120.00 & 31.51 & 26.25 \\
\hline 2003-04 & 145.00 & 169.53 & 116.91 \\
\hline 2004-05 & 40.00 & 44.24 & 110.60 \\
\hline 2005-06 & $\begin{array}{l}\text { No target } \\
\text { fixed }\end{array}$ & 15.81 & - \\
\hline 2006-07 & $\begin{array}{c}\text { No target } \\
\text { fixed }\end{array}$ & 5.34 & - \\
\hline 2007-08 & $\begin{array}{c}\text { No target } \\
\text { fixed }\end{array}$ & 387.95 & - \\
\hline 2008-09 & $\begin{array}{c}\text { No target } \\
\text { fixed }\end{array}$ & 5.66 & - \\
\hline 2009-10 & $\begin{array}{l}\text { No target } \\
\text { fixed }\end{array}$ & 245.81 & - \\
\hline 2010-11 & 400.00 & 228.46 & 57.11 \\
\hline 2011-12 & 400.00 & 180.88 & 45.22 \\
\hline 2012-13 & 300.00 & 258.90 & 86.30 \\
\hline 2013-14 & 400.00 & 293.68 & 73.42 \\
\hline 2014-15 & 434.25 & 377.37 & 86.90 \\
\hline 2015-16 & 410.00 & 421.32 & 102.76 \\
\hline 2016-17 & 565.00 & 455.00 & 80.53 \\
\hline 2017-18 & 725.00 & 725.00 & 100.00 \\
\hline
\end{tabular}

Source: (Basic data) Handbook of Statistics on the Indian Economy various issues, Budget 2017-18 and Public Enterprises Survey 2017-18

\section{UTILIZATION OF MONEY FROM DISINVESTMENT}

When the programme of disinvestment was initiated in 1991-91, the Finance Minister had stated that a part of the proceeds would be used for providing resources in the National Renewal Fund (NRF) which can be used for various schemes of assistance to workers to the unorganized sector. Moreover, these "non-inflationary resources would also be used to fund.... special employment creating schemes in backward areas”. In 1997, the first report of the Disinvestment Commission headed by G. V. Ramakrishna stated that the proceeds of disinvestment should not be used to bridge the budget deficit, but instead should be placed in a separate fund to be used for four purposes:

1. Retiring public debt

2. Restructuring PSUs

3. Developing the social infrastructure; and

4. Voluntary retirement schemes.

Similar sentiments were expressed in various budget speeches of the Finance Ministers in different years. For the year 2001-02, the Finance Minister had set the target for disinvestment at Rs.120.00 Billion of which Rs.70.00 Billion was to be used to provide "restructuring assistance to PSUs, a safety net to workers and reduction of (the public) debt burden” while the remaining Rs.50.00 Billion was to be used to provide "additional budgetary support to the plan primarily in the social and infrastructure sectors”.

One cannot but fully agree with the then Prime Minister of India Dr. Manmohan Singh, the architect of India's economic reforms, when he said during the Budget speech 1998-99,

"Privatisation should no longer be seen as an instrument of reducing the budget deficit. It must have a wider purpose. The proceeds of privatization or disinvestment must be used for three purposes. First, to strengthen the better off PSEs and make them even more competitive. Secondly, some of the funds must be used to finance specific social programmes such as public education and health. This is what Mexico did, and this is vital to gain political acceptability for privatization. Finally, some of the proceeds must be used as a seed capital to strengthen infrastructure” (GoI, 1998).

The policy on disinvestment as announced by Union Budget 2006-07 was that the proceeds from this source would be credited to National Investment Fund (NIF) and only interest income would be used to finance expenditure. This was relaxed in 2009-10 as a temporary measure to meet social expenditure, till the year 2011-12. The list of objectives of disinvestment given earlier also expressed such lofty ideals. However, the actual experience with the utilization of disinvestment proceeds during the last decades belies all these declarations. The government has used the entire proceeds from disinvestment to offset the shortfalls in revenue receipts and thus reduce the fiscal deficit which it was required to do as part of the IMF stabilization programme. In this context, the following comments of Chandrashekhar and Ghosh are relevant; "The experience suggests that the fiscal convenience was the prime mover of such disinvestment. Having internalized the IMF prescription that reducing or doing away with fiscal deficits is the prime indicator of good macroeconomic management, the government found privatization proceeds of PSUs to be useful source of revenue to window-dress budgets" (Chandrashekhar and Ghosh, 2002: 38-39). Thus, the resources generated from the disinvestment of PSUs have 
been used to meet current consumption needs (see Table 2). This amount to fritting away valuable public assets.

Moreover, once a PSU is privatized, the government is deprived of the future yields from this enterprise. This could be a sizeable long-term loss in the case of profit-generating PSUs. These points to the shortsightedness of the government's disinvestment programme.

TABLE II DISINVESTMENT PROCEEDS SINCE 1991 (IN BILLION RUPEES) AND PERCENTAGE REDUCTION IN FD

\begin{tabular}{|c|c|c|c|}
\hline Year & Disinvestment & $\begin{array}{c}\text { \% of Capital } \\
\text { Receipts }\end{array}$ & $\begin{array}{c}\text { \% Change } \\
\text { in FD }\end{array}$ \\
\hline $1991-92$ & 30.38 & 7.89 & 7.72 \\
\hline $1992-93$ & 19.61 & 5.42 & 4.65 \\
\hline $1993-94$ & -0.48 & -0.09 & -0.08 \\
\hline $1994-95$ & 50.78 & 7.39 & 8.08 \\
\hline $1995-96$ & 3.62 & 0.62 & 0.59 \\
\hline $1996-97$ & 3.80 & 0.62 & 0.56 \\
\hline $1997-98$ & 9.12 & 0.92 & 1.01 \\
\hline $1998-99$ & 58.74 & 4.52 & 4.92 \\
\hline $1999-00$ & 17.24 & 1.49 & 1.61 \\
\hline $2000-01$ & 21.25 & 1.58 & 1.75 \\
\hline $2001-02$ & 36.46 & 2.24 & 2.52 \\
\hline $2002-03$ & 31.51 & 1.75 & 2.12 \\
\hline $2003-04$ & 169.53 & 8.02 & 12.08 \\
\hline $2004-05$ & 44.24 & 2.21 & 3.39 \\
\hline $2005-06$ & 15.81 & 0.88 & 1.06 \\
\hline $2006-07$ & 5.34 & 0.37 & 0.37 \\
\hline $2007-08$ & 387.95 & 19.60 & 23.41 \\
\hline $2008-09$ & 5.66 & 0.19 & 0.16 \\
\hline $2009-10$ & 245.81 & 5.43 & 5.54 \\
\hline $2010-11$ & 228.46 & 5.68 & 5.76 \\
\hline $2011-12$ & 180.88 & 3.18 & 3.38 \\
\hline $2012-13$ & 258.90 & 4.45 & 5.01 \\
\hline $2013-14$ & 293.68 & 5.21 & 5.51 \\
\hline $2014-15$ & 377.37 & 7.79 & 6.88 \\
\hline $2015-16$ & 421.32 & 7.23 & 7.32 \\
\hline $2016-17$ & 455.00 & 8.26 & 7.84 \\
\hline $2017-18$ & 725.00 & 11.73 & 11.71 \\
\hline
\end{tabular}

Source: (Basic data) Handbook of Statistics on the Indian Economy 201617, Budget 2017-18

The government does not provide any break-up of the use of money obtained from disinvestment. However, from the failure of the Board for Industrial and Financial Reconstruction (BIFR) route and setting up of a new body called Board for Reconstruction of Public Sector Enterprises, it is clear that the disinvestment proceeds have helped very little for the revival of sick PSUs. According to the Budget Speech of 2000-01, the other two purposes for which the disinvestment proceeds are to be utilized are: (i) for meeting expenditure in social sectors and (ii) for reducing public debt.
But for Table 3, it appears that neither in case of social sector nor in respect of public debt the disinvestment has been able to extent any impact. In comparison with the beginning year of economic reform, the debt position as a percentage of GDP has gone up substantially in 2002-03 and 2003-04.

And, the expenditure in social sectors, which was supposed to go up, has come down gradually in 2002-03 and 2003-04. From this, it may be presumed that the main rationale behind the so-called reform is, to raise only the noninflationary form of finance so that the fiscal deficit is bridged (Misra and Puri, 2001).

TABLE III PUBLIC DEBT AND EXPENDITURE IN SOCIAL SECTORS

\begin{tabular}{|c|c|c|}
\hline Year & $\begin{array}{c}\text { Debt as a \% of } \\
\text { GDP* }\end{array}$ & $\begin{array}{c}\text { Social sector } \\
\text { expenses as a \% of } \\
\text { Total Expenditure }\end{array}$ \\
\hline 1991-92 & 75.17 & 21.25 \\
\hline 1992-93 & 74.27 & 21.41 \\
\hline 1993-94 & 74.66 & 19.44 \\
\hline 1994-95 & 72.24 & 21.09 \\
\hline 1995-96 & 69.39 & 19.65 \\
\hline 1996-97 & 66.38 & 18.53 \\
\hline 1997-98 & 68.37 & 19.07 \\
\hline 1998-99 & 69.21 & 19.47 \\
\hline $1999-2000$ & 72.68 & 20.45 \\
\hline 2000-01 & 75.98 & 22.03 \\
\hline 2001-02 & 81.26 & 22.32 \\
\hline 2002-03 & 85.46 & 25.12 \\
\hline 2003-04 & 85.84 & 22.94 \\
\hline 2004-05 & 84.71 & 23.09 \\
\hline 2005-06 & 81.55 & 26.31 \\
\hline 2006-07 & 77.00 & 24.47 \\
\hline 2007-08 & 73.68 & 24.27 \\
\hline 2008-09 & 74.47 & 30.91 \\
\hline 2009-10 & 72.82 & 29.72 \\
\hline $2010-11$ & 67.65 & 33.77 \\
\hline 2011-12 & 67.35 & 33.50 \\
\hline 2012-13 & 66.65 & 32.49 \\
\hline 2013-14 & 67.05 & 30.68 \\
\hline 2014-15 & 66.69 & 27.64 \\
\hline 2015-16 & 68.60 & 27.65 \\
\hline 2016-17 & 67.67 & 31.92 \\
\hline 2017-18 & 67.62 & 32.57 \\
\hline
\end{tabular}

Note: *Total government debt including domestic and external debts of the Centre and State governments Source:(Basic data)Handbook of Statistics on the Indian Economy2016-17 
But the figures in Table IV reveal that the aim of the government to mitigate the deficit financing too has not materialized through disinvestment process.

The realization from disinvestment is so meagre in proportion to the total deficit during the decade that it actually matters little whether disinvestment is resorted to or not. The last column of table also reflects that the socalled economic reforms during last 1990s have failed miserably to arrest the fiscal deficit within a reasonable limit.

The ever-increasing trend in fiscal deficit as a percentage of GDP has indeed put a big question mark on the justification of privatization by way of disinvestment.

TABLE IV DEFICIT FINANCING AND DISINVESTMENT PROCEEDS

\begin{tabular}{|c|c|c|}
\hline Year & $\begin{array}{c}\text { Disinvestment } \\
\text { as a \% of FD }\end{array}$ & FD as a $\%$ of GDP \\
\hline 1991-92 & 8.36 & 5.56 \\
\hline 1992-93 & 4.88 & 5.35 \\
\hline 1993-94 & -0.08 & 6.97 \\
\hline 1994-95 & 8.80 & 5.69 \\
\hline 1995-96 & 0.60 & 5.07 \\
\hline 1996-97 & 0.57 & 4.85 \\
\hline 1997-98 & 1.03 & 5.83 \\
\hline 1998-99 & 5.18 & 6.48 \\
\hline $1999-2000$ & 1.65 & 5.34 \\
\hline 2000-01 & 1.79 & 5.63 \\
\hline 2001-02 & 2.59 & 6.17 \\
\hline 2002-03 & 2.17 & 5.90 \\
\hline 2003-04 & 13.75 & 4.47 \\
\hline 2004-05 & 3.52 & 4.00 \\
\hline 2005-06 & 1.08 & 4.09 \\
\hline 2006-07 & 0.37 & 3.42 \\
\hline 2007-08 & 30.57 & 2.62 \\
\hline 2008-09 & 0.17 & 6.17 \\
\hline 2009-10 & 5.87 & 6.66 \\
\hline 2010-11 & 6.12 & 4.95 \\
\hline 2011-12 & 3.51 & 5.91 \\
\hline $2012-13$ & 5.28 & 4.93 \\
\hline 2013-14 & 5.84 & 4.48 \\
\hline 2014-15 & 7.39 & 4.10 \\
\hline 2015-16 & 7.91 & 3.89 \\
\hline 2016-17 & 8.52 & 3.52 \\
\hline 2017-18 & 12.27 & 3.46 \\
\hline
\end{tabular}

Source: (Basic data) Handbook of Statistics on the Indian Economy, various issues

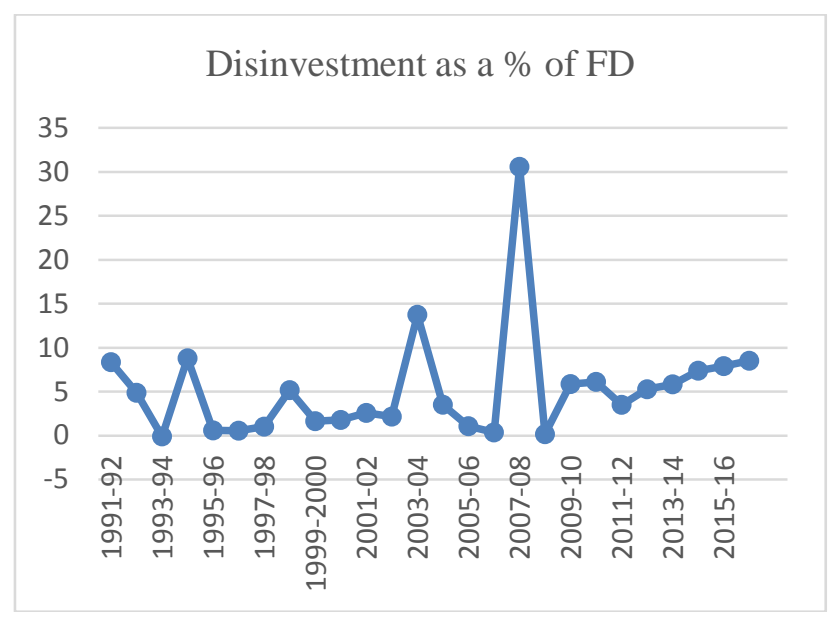

Fig.1 Disinvestment Receipts as a Percentage of Fiscal Deficit

Improvement in efficiency should be the primary objective of privatization. This objective can be achieved when inefficient public sector units are privatized. Instead, in the last decade, some of the best performing units have been sold off. Most of the blue-chip companies were sold at very low prices.

The distress sale was a result of an inappropriate pricing strategy and delays in pricing. The delay in pricing the Videsh Sanchar Nigam Limited (VSNL) issue resulted in a massive loss to the nation. The same mistake was the fact that it is the market that determines the price of a PSU stock.

In the case of a strategic sale of a unit, the government did not put in substantial efforts to restructure or market the PSUs. Hence, most of the time, it ended up selling a company cheap. For instance, the restructuring of Paradeep Phosphates was incomplete, and it was sold off at a low price to Zuari Macro Phosphate. The restructuring of a unit should be of both financial and operational nature.

Significant disinvestment steps were taken in the past by BJP-led NDA government (1999-2004), made for strategic disinvestments in Bharat Aluminium Company (BALCO) and Hindustan Zinc (both to Sterlite Industries), Indian Petrochemicals Corporation Limited (to Reliance Industries) and VSNL (to the Tata group), while the track records of these companies were profitable.The NDA government has also been criticized for disinvestment of IPCL, in which Reliance Industries bid very high as compared to other competitors. Again, in starting from 2014 to 2018 NDA government divested total Rs.1946.46 Billion, which also includes minority and majority stake sale of most profitable PSUs, like ONGC, HPCL.

In the budgetary announcement of the financial year 201718, the Finance Minister noted that the government initiated strategic disinvestment in 24 PSUs, including Air India. 


\section{CONCLUSION}

To sum up, the main factors responsible for poor outcome of disinvestment in India include the lack of an overall strategy for disinvestment; the absence of systematic efforts to restructure and prepare enterprises for disinvestment; the arbitrary selection of enterprises for disinvestment without any consultation with them; a high degree of secrecy; the lack of objectivity in the share of valuation methods; and lack of incentives for enterprises to participate enthusiastically in the programmes (for example, there was no provision for enterprises to retain a percentage of the disinvestment proceeds); opposition from the relevant administrative ministry, employees, trade unions and interest groups; lack of domestic capital and lukewarm response of foreign capital and above all lack of political consensus on disinvestment. Above all, the disinvestment proceeds in India have been utilised for financing the fiscal deficit rather than fulfilling the declared objectives of it. For the last few years, the government has been strategically disinvesting even the better performing PSUs just to cover up the deficits. In the years the government was successfully able to get relatively large disinvestment proceeds, the deficit figure of the Central Government was artificially reduced. This measure can give temporary relief from the soaring fiscal deficit problem in India, while its long-run consequences will be drastic.

\section{REFERENCES}

[1] Butler, S.M. (1986). Privatizing Government Services, Impact, $3(21)$.

[2] Chandrashekhar, C.P.,\& Jayati Ghosh. (2002). The Market That Failed: A Decade of Neoliberal Economic Reforms in India, New Delhi,89.

[3] Chelliah, R. J. (1996). Towards Sustainable Growth: Essays in Fiscal and Financial Sector Reforms in India, OUP, New Delhi.

[4] Government of India, Ministry of Finance, Budget documents, Various Issues.

[5] Government of India, Ministry of Finance, Handbook of Statistics of the Indian Economy, Various Issues.

[6] Government of India, Ministry of Finance, Working Group Report on Centre's Financial Resources. 2012: 4.

[7] Government of India, Ministry of Heavy Industries and Public Enterprises Department, Public Enterprises Survey, Various Issues.

[8] Gupta, K.L. (1998). Public Enterprises in India, Navyug Sahitya Sadan, Agra, 77.

[9] Jalan, B. (1992). India's Economic Policy-Preparing for the Twenty First Century, Penguine Books, New Delhi, 21.

[10] Kumar, A. (1994), (April 16-23), Growth Prospects Recede as Macro-Economic Situation Slips Out of Control, Economic and Political Weekly, 953-968.

[11] Mansoor, A. M. (1988). The Budgetary Impact of Privatization” in Blejer, Mario I and Chu, Ke-young (ed.), Measurement of Fiscal Impact Methodological Issues, IMF Occasional Paper No. 59.

[12] Misra, S.K.,\& Puri, V.K. (2001). Indian Economy, Himalaya Publishing House, New Delhi.

[13] Pendse, D.R. (1985). Privatization and Economic Growth, Forum of Free Enterprises, 85.

[14] Rubi \& Shagufta (2008). Policies, Issues and Pattern of Disinvestment in India since Liberalisation: A Case Study of Videsh Sanchar Nigam Limited. Thesis submitted to Aligarh Muslim University, Aligarh.

[15] Stiglitz \& Joseph (2003). The Roaring Nineties: Seeds of Destruction, Allen Books. 